\title{
Determination of Allelopathic Potential in Mahogany (Swietenia macrophylla King) Leaf Litter Using Sandwich Method
}

\author{
Arnia Sari Mukaromah ${ }^{1,}{ }^{*}$, Yekti Asih Purwestri ${ }^{1}$, and Yoshiharu Fujii ${ }^{2}$ \\ ${ }^{1}$ Faculty of Biology, Universitas Gadjah Mada, Jalan Teknika Selatan, Sekip Utara, \\ Yogyakarta 55281, Indonesia \\ ${ }^{2}$ Departement of International Environmental and Agricultural Science, \\ Tokyo University of Agriculture and Technology, Tokyo 183-0057, Japan
}

\begin{abstract}
The sandwich method is a reliable screening bioassay that can be utilized to investigate allelopathic activity of leaf litter leachates. Screening the allelopathic potential of mahogany (Swietenia macrophylla King) leaf litter in plant-plant interaction using the sandwich bioassay method has not been reported. The research objectives were to determine and categorize allelopathic potential of $S$. macrophylla leaf litter using the sandwich bioassay method, and to determine specific activity $\left(\mathrm{EC}_{50}\right)$ of $S$. macrophylla leaf litter. The results showed that $S$. macrophylla leaf litter exhibited strong allelopathic activity when compared with 46 leaf litter species and was included in the top ten of allelopathic leaf litter species. Increasing $S$. macrophylla leaf litter concentration was concomitant with inhibition of radicle lettuce seedling growth compared with the control. According to the linear regression analysis, the effective concentration $\left(\mathrm{EC}_{50}\right)$ of S. macrophylla was estimated to be $3.25 \mathrm{mg}$ D.W. eq. $\mathrm{mL}^{-1}$ and was considered to have strong growthinhibitory activity on lettuce radicle elongation. The results suggest the possibility of allelopathic potential of leaf litter in plant-plant interaction under S. macrophylla trees.
\end{abstract}

Keywords: Allelopathy, $\mathrm{EC}_{50}$, leaf litter, mahogany, Sandwich Method

\section{Introduction}

Allelopathy is one of the interactions that have contributed to inducing biological phenomena in the environment. Allelopathy is described as chemical interactions between plant-plant, plant-microorganism, and plant-animal, whether stimulatory or inhibitory of growth and development (Rice, 1984; Einhelling, 1995; Blum, 2011; Gniazdowska and Bogatek, 2005). The major constituent of allelochemicals are secondary metabolites that influence vegetation community patterns and succession, germination of seeds or fungi spores, the nitrogen cycle, crop productivity, and plant protection (Einhelling, 1995; Gniazdowska and Bogatek, 2005). Allelochemicals have been applied in sustainable weed

\section{*Corresponding author:}

Arnia Sari Mukaromah

Faculty of Biology, Universitas Gadjah Mada, Jalan Teknika Selatan, Sekip Utara, Yogyakarta 55281, Indonesia

E-mail: arnia.sari.m@mail.ugm.ac.id management and agricultural pest management because they are environmentally friendly, biodegradable, and can reduce the utilization of herbicide. In the field, allelopathic plants have been applied as cover and smother crops, mulching, intercropping, crop rotation, green manure, and natural pesticide (Farooq et al., 2011; Jabran et al., 2015; Singh et al., 2003).

Mahogany (Swietenia macrophylla King), a tropical timber tree species with high-quality wood, has been cultivated in Indonesia since it was introduced in 1870 (Whitemore, 2003; Krisnawati et al., 2011). S. macrophylla is another famous member of the Meliaceae family besides Azadirachta indica. S. macrophylla has great potential applications, such as the protection of slopes, water catchment, avenue, furniture and cabinet making (Krisnawati et al., 2011), compost fertilizer (Nugroho, 2014), antimicrobial, anti-inflammatory, antioxidant, antimutagenic, anticancer, antidiabetic, antidiarrhoeal, antiviral, antimalarial, hypolipidemic activities (Moghadamtousi et 
al., 2013) and heavy metal phytoremediation (Fan et al., 2011). Meanwhile, mahogany leaf litter is one of the source of potent allelopathic substances which can inhibit sunflower (Helianthus annuus L.) seed germination and phenolic compound produced throughout decomposition of $S$. macrophylla leaf litter inhibit acacia (Acacia mangium Wild.) seedling growth (Muhartini, 1987; Tambaru, 1998). Germacrene D and $\mathrm{y}$-himachalene of $S$. macrophylla leaves may play important role in attracting mahogany shoot borer (Hypsipyla grandella) to oviposit on mahogany leaves (Soares et al., 2003). Furthermore, ethanol extracts of $S$. macrophylla leaves reveal acaricidal activity to Varroa destructor mites inside colonies of honeybees (El Zalabani et al., 2012).

Central Java and West Java have contributed as much as $60 \%$ of the total number of mahogany trees in Indonesia, and have produced abundant leaf litter that has not been maximally used (Krisnawati et al., 2011; Nugroho, 2014). Mahogany that has a diameter of $29 \mathrm{~cm}$, height of $15 \mathrm{~m}$ and canopy thickness of $4.5 \mathrm{~m}$ produces $1296.94 \mathrm{~g} / \mathrm{m}^{2} /$ year of leaf litter, with the highest leaf litter production occurring in May-June (dry season) at 89.24 $\mathrm{g} / \mathrm{m}^{2} /$ week (Nugroho, 2014). Allelochemicals are transferred to the environment by leaching from leaves or other aerial parts, volatile emissions, root exudation, and decomposition of plant residue (Weir et al., 2004).

Preliminary studies can be utilized to indicate allelopathic activity. Several preliminary approaches have been developed such as growing the receiver plant with plant residues or watering the receiver plant with leaf leachate (Duke, 2015). However, the previous preliminary studies need extraction procedure, and suitable for a small number of samples. The sandwich method are very useful allelopathic screening for leaf leachate under laboratory conditions (Fujii et al., 2003). The sandwich method is a reliable, fast, easy bioassay and can screen a large number of samples from leaf litter leachates. It has screened more than 852 species (Fujii et al., 2003; Fujii et al., 2004; Appiah et al., 2015; Mardani et al., 2016; Morikawa et al., 2012).
Nevertheless, to date, screening of the allelopathic potential of $S$. macrophylla leaf litter in plant-plant interaction using the sandwich bioassay method and investigation of growth-inhibitory activity have not been reported. The objectives of this research were to determine and categorize allelopathic potential of $S$. macrophylla leaf litter using the sandwich bioassay method, and to determine specific activity $\left(\mathrm{EC}_{50}\right)$ of $S$. macrophylla leaf litter.

\section{Materials and Methods}

\section{Plant materials}

S. macrophylla leaf litter were collected from Bawen village, Semarang regency, Central Java, Indonesia, in the end of August 2015, and then identified in the Laboratory of Plant Systematics at the Faculty of Biology, Universitas Gadjah Mada, Indonesia. Comparing leaf litter species were collected from Tsukuba Botanical Garden, Koishikawa Botanical Garden, Yumenoshima Botanical Garden, Jindai Botanical Garden, and Tokyo University of Agriculture and Technology, Fuchu campus, on February 11 to March 2, 2016. Each sample was placed into a separate paper bag and used for laboratory studies in the Laboratory of International AgroBiological Resources and Allelopathy at Tokyo University of Agriculture and Technology, Japan.

\section{Sandwich method}

The sandwich method procedure was adopted from Fujii et al. (2003), Fujii et al.(2004), and Morikawa et al.(2012). The amount of leaf litter sample (either $10 \mathrm{mg}$ or $50 \mathrm{mg}$ ) was placed into a six well $\left(\sim 10 \mathrm{~cm}^{2}\right.$ area per well) multi-dish plate $(36 \mathrm{~mm} \times 18 \mathrm{~mm}$, Nalge Nunc Int.) with specifity (each well in upper row for $10 \mathrm{mg}$ and lower row for $50 \mathrm{mg}$ ). Agar powder (Nacalai Tesque, Kyoto, Japan, with a gelling temperature of $30-31^{\circ} \mathrm{C}$ ) was prepared as $0.75 \%(\mathrm{w} / \mathrm{v})$ and autoclaved at $115^{\circ} \mathrm{C}$ for $15 \mathrm{~min}$ (Sanyo, Japan). The autoclaved agar was cooled down to ca. $45^{\circ} \mathrm{C}$ in a water bath. The first layer of autoclaved agar $(5 \mathrm{~mL})$ was added to each well using a pipette (Gilson Co. Ltd., Villiers-le-Bel, 
France). After gelatinization, the second layer of autoclaved agar $(5 \mathrm{~mL})$ was added to each well and gelatinized for 30-60 min at room temperature. Five seeds of lettuce (Lactuca sativa L. var. Legacy; Takii Company, Kyoto, Japan) were sown in the surface of the second layer of agar and limited of sowing time could prevent contamination. The multi-dish was covered and sealed with a cellophane adhesive tape. Furthermore, it was wrapped with aluminum foil, and incubated in an incubator (NTS Model MI-25S) at $22^{\circ} \mathrm{C}$ for 72 hours (3 days). The lengths of the radicle and hypocotyl were measured using a graphing paper. These data were used to calculate the elongation percentage compared with the control (Eq. 1).

Elongation $(\%)=\frac{\begin{array}{c}\text { average length of } \\ \text { radicle } / \text { hypocotyl }\end{array}}{\begin{array}{c}\text { average length of } \\ \text { control radicle/hypocotyl }\end{array}} \times 100 \quad$ (Eq. 1)

\section{Preparation of test solution}

Five milligrams of $S$. macrophylla dried leaf litter was soaked in $50 \mathrm{~mL}$ of methanol $90 \%$ and incubated for 24 hours. Crude extract of $S$. macrophylla leaf litter was filtered using filter paper (125 mm ø, Toyo Roshi Kaisha, Ltd., Tokyo). S. macrophylla leaf litter extraction was repeated twice, collected in an Erlenmeyer flask (Pyrex), and used as test solution. The final concentration ranged from 1 to $9 \mathrm{mg}$ dry weight equivalent $\mathrm{mL}^{-1}$ (mg D.W. eq. $\mathrm{mL}$ ).

\section{Growth-inhibitory activity bioassay}

The growth-inhibitory activity bioassay was adopted from Takemura et al.(2013). Filter paper (27 mm ø, Toyo Roshi Kaisha, Ltd., Tokyo) was placed into a glass Petri dish $(27 \mathrm{~mm} ø)$. The test solution $(700 \mu \mathrm{L})$ was added into the filter paper in the Petri dish and dried completely in vacuo (Eyela NVC2200 and Eyela DPE-1130). After distilled water was added $(700 \mu \mathrm{L}), 5$ pre-germinated (18 $\mathrm{h}$ at $22^{\circ} \mathrm{C}$ in the dark) seedlings of lettuce (Lactuca sativa L. var. Legacy; Takii Company, Kyoto, Japan) were placed on the filter paper. All of the Petri dishes were placed in the same chamber and wrapped with aluminum foil and incubated in an incubator (NTS Model MI-25S) at $22^{\circ} \mathrm{C}$ for 48 hours. After incubation, the lengths of the radicle and hypocotyl were measured using a graphing paper. These data were used to calculate the elongation percentage compared with the control (Eq. 1).

\section{Statistical analysis}

The experiment was conducted using a completely randomized design with three independent replications. Either the radicle or hypocotyl elongation percentage was calculated (Eq. 1) and confirmed with a normal distribution curve. Categorization of strength inhibitory activity was calculated by "Standard Deviation Variance" (SDV) based on radicle elongation of $50 \mathrm{mg}$ of dried leaf litter. In the statistical analysis, evaluation of the mean $(\mathrm{M})$, standard deviation (SD), and SD variance (SDV) were calculated using Microsoft Excel ver. $2013^{\circledR}$. The effective concentration required to induce half-maximal inhibition of growth $\left(\mathrm{EC}_{50}\right)$ was calculated by linear regression analysis using Microsoft Excel ver. $2013^{\circledR}$.

\section{Results and Discussion}

\section{Allelopathic potential of S. macrophylla leaf litter on lettuce growth}

The allelopathic potential categorization was utilized to observe allelopathic activity of S. macrophylla compared with the other leaf litter species. The number of comparator leaf litter species were as well as more than 50 leaf litter species. However, S. macrophylla only compared with 46 leaf litter species from 22 families because several leaf litter species did not have suitable sample weight for assessment. The most abundant species belonged to Cupressaceae ( 9 species), Pinaceae (6 species), Podocarpaceae (6 species), Acanthaceae (2 species), Verbenaceae (2 species), followed by one species from each of the other families. Meanwhile, the lettuce seeds, a small seeded species were used as test plant material in the sandwich bioassay method because of their rapid germination, homogeneity and high sensitivity to the phytotoxic compound. It had similar character with lettuce (L. sativa 'Great Lakes 366') seeds 
used in the previous sandwich bioassay method (Fujii et al., 2007).

The allelopathic potential of the leaf litter samples was determined by "Standard Deviation Variance" (SDV) method based on radicle elongation in $50 \mathrm{mg}$ D.W. and then compared with other leaf litter species.
According to Table 1, S. macrophylla leaf litter exhibited strong allelopathic activity when compared with 46 other leaf litter species, and included in the top ten of allelopathic leaf litter species. This could be related to previous allelopathy research showing that S. macrophylla leaf litter inhibited the

Table 1. Allelopathic activity of 47 leaf litter species using sandwich method.

\begin{tabular}{|c|c|c|c|c|c|c|c|}
\hline \multirow{3}{*}{ Plant families } & \multirow{3}{*}{$\begin{array}{l}\text { Collection } \\
\text { site† }\end{array}$} & \multirow{3}{*}{ Scientific name } & \multicolumn{4}{|c|}{$\begin{array}{l}\text { Dry leaf content } \\
\left.(10 \mathrm{ml} \mathrm{agar})^{-1}\right)\end{array}$} & \multirow{3}{*}{$\begin{array}{l}\text { Criteria } \\
\quad(*)\end{array}$} \\
\hline & & & \multicolumn{2}{|c|}{$10 \mathrm{mg}$} & \multicolumn{2}{|c|}{$50 \mathrm{mg}$} & \\
\hline & & & $\mathrm{R} \%$ & $\mathrm{H} \%$ & $\mathrm{R} \%$ & $\mathrm{H} \%$ & \\
\hline Verbenaceae & YMBG & Duranta repens L. & 29 & 54 & 9 & 28 & $* * * *$ \\
\hline Plumbaginaceae & YMBG & Plumbago auriculata Lam. & 54 & 112 & 15 & 74 & $* * *$ \\
\hline Meliaceae & INDO & Swietenia macrophylla King & 59 & 102 & 19 & 72 & $* * *$ \\
\hline Solanaceae & YMBG & Brunfelsia australis Benth. & 30 & 57 & 20 & 69 & $* * *$ \\
\hline Moraceae & YMBG & Ficus superba Miq. & 54 & 84 & 24 & 50 & $* *$ \\
\hline Berberidaceae & TKBG & Nandina domestica Thunb. & 34 & 69 & 25 & 72 & $* *$ \\
\hline Myrtaceae & YMBG & $\begin{array}{l}\text { Feijoa sellowiana(O. Berg.) O. } \\
\text { Berg. }\end{array}$ & 73 & 112 & 33 & 84 & $* *$ \\
\hline Pinaceae & TKBG & Pinus densiflora Siebold \& Zucc. & 97 & 84 & 36 & 65 & $* *$ \\
\hline Theaceae & KSBG & $\begin{array}{l}\text { Camellia japonica L. F. leunctha } \\
\text { Makino }\end{array}$ & 54 & 66 & 37 & 67 & $* *$ \\
\hline Pinaceae & TKBG & Tsuga sieboldii Carrière & 76 & 84 & 38 & 78 & * \\
\hline Cupressaceae & KSBG & Taxodium distichum (L.) Rich. & 87 & 91 & 39 & 64 & * \\
\hline Celastraceae & KSBG & Euonymus chibae Makino & 88 & 103 & 42 & 78 & * \\
\hline Acanthaceae & YMBG & $\begin{array}{l}\text { Strobilanthes anisophyllus (G. } \\
\text { Lodd.) T. Anders. }\end{array}$ & 81 & 98 & 46 & 119 & * \\
\hline Linaceae & YMBG & Reinwardtia indica Dumort. & 78 & 79 & 48 & 92 & * \\
\hline Podocarpaceae & TKBG & Saxegothaea conspicua Lindl. & 82 & 97 & 50 & 87 & * \\
\hline Hamamelidaceae & KSBG & Hamamelis mollis Oliv. & 108 & 98 & 53 & 92 & \\
\hline Verbenaceae & YMBG & Lantana camara L. & 88 & 89 & 54 & 108 & \\
\hline Pinaceae & KSBG & Pinus koraiensis Siebold \& Zucc. & 104 & 87 & 57 & 65 & \\
\hline Fagaceae & TKBG & Quercus sessiliflolia Salisb. & 87 & 98 & 58 & 106 & \\
\hline Pinaceae & JDBG & Abies sachalinensis Mast. & 100 & 92 & 63 & 79 & \\
\hline Acanthaceae & YMBG & Eranthemum pulchellum Andrews & 103 & 99 & 64 & 107 & \\
\hline Cupressaceae & JDBG & $\begin{array}{l}\text { Cyrptomeria japonica (Thunb. ex } \\
\text { L.f.) D. Don }\end{array}$ & 84 & 74 & 65 & 71 & \\
\hline Pinaceae & JDBG & Pinus ellioti 'Elliotti' Engelm & 89 & 86 & 68 & 86 & \\
\hline Cupressaceae & JDBG & $\begin{array}{l}\text { Thujopsis dolabrata (Thunb. ex } \\
\text { L.f.) Siebold \& Zucc. }\end{array}$ & 94 & 116 & 70 & 122 & \\
\hline Cupressaceae & JDBG & $\begin{array}{l}\text { Chamaecyparis pisifera } \\
\text { (Siebold \& Zucc.) Endl. 'Filifera' }\end{array}$ & 103 & 101 & 70 & 91 & \\
\hline Pinaceae & KSBG & Cedrus deodara (Roxb.) G. Donn f. & 93 & 86 & 70 & 86 & \\
\hline Ericaceae & KSBG & $\begin{array}{l}\text { Rhododendron macrosepalum } \\
\text { Maxim }\end{array}$ & 127 & 115 & 71 & 129 & \\
\hline Cupressaceae & KSBG & Juniperus luthuensis Koidz. & 83 & 95 & 74 & 100 & \\
\hline Caprifoliaceae & YMBG & Lonicera periclymenum L. & 111 & 112 & 75 & 110 & \\
\hline Araliaceae & TKBG & $\begin{array}{l}\text { Dendropanax trifidus (Thunb.) } \\
\text { Makino ex Hara }\end{array}$ & 93 & 104 & 75 & 124 & \\
\hline Cannabaceae & TKBG & Celtis sinensis Pers. & 117 & 109 & 76 & 100 & \\
\hline
\end{tabular}


Table 1. Allelopathic activity of 47 leaf litter species using sandwich method (cont.).

\begin{tabular}{|c|c|c|c|c|c|c|c|}
\hline \multirow{3}{*}{ Plant families } & \multirow{3}{*}{$\begin{array}{l}\text { Collection } \\
\text { site }\end{array}$} & \multirow{3}{*}{ Scientific name } & \multicolumn{4}{|c|}{$\begin{array}{l}\text { Dry leaf content } \\
\left(10 \mathrm{ml} \mathrm{agar}^{-1}\right)\end{array}$} & \multirow{3}{*}{ Criteria } \\
\hline & & & \multicolumn{2}{|c|}{$10 \mathrm{mg}$} & \multicolumn{2}{|c|}{$50 \mathrm{mg}$} & \\
\hline & & & $\mathrm{R} \%$ & $\mathrm{H} \%$ & $\mathrm{R} \%$ & $\mathrm{H} \%$ & \\
\hline Podocarpaceae & TKBG & Podocarpus nivalis Hook. & 100 & 107 & 81 & 123 & \\
\hline Symplocaceae & TKBG & Symplocos sawafutagi H. Nagamasu & 123 & 106 & 82 & 106 & \\
\hline Ericaceae & TKBG & Rhododendron hyperythrum Hayata & 109 & 112 & 83 & 120 & \\
\hline Ericaceae & KSBG & $\begin{array}{l}\text { Rhododendron transiens Nakai cv } \\
\text { Hatrusimo }\end{array}$ & 104 & 112 & 84 & 114 & \\
\hline Cupressaceae & KSBG & $\begin{array}{l}\text { Chamaecyparis obtusa (Siebold \& } \\
\text { Zucc.) Siebold \& Zucc. Ex Endl. }\end{array}$ & 105 & 106 & 85 & 128 & \\
\hline Cupressaceae & JDBG & $\begin{array}{l}\text { Cunninghamia lanceolata (Lamb.) } \\
\text { Hook. }\end{array}$ & 106 & 99 & 86 & 105 & \\
\hline Proteaceae & YMBG & Banksia ericifolia L.f. & 103 & 93 & 91 & 108 & \\
\hline Cupressaceae & TKBG & $\begin{array}{l}\text { Sequoia sempervirens (Lamb. Ex D. } \\
\text { Don) Endl. }\end{array}$ & 109 & 90 & 91 & 94 & \\
\hline Ericaceae & KSBG & Rhododendron socibrum D. Dm. & 114 & 108 & 92 & 130 & \\
\hline Ericaceae & KSBG & $\begin{array}{l}\text { Rhododendron pulchrum Sweet cv. } \\
\text { Sen-e-ohmurasaki }\end{array}$ & 121 & 116 & 92 & 130 & \\
\hline Ericaceae & KSBG & Rhododendron hybrida Has & 125 & 122 & 96 & 134 & \\
\hline Ericaceae & KSBG & $\begin{array}{l}\text { Rhododendron transiens Nakai cv } \\
\text { Asukagawa }\end{array}$ & 116 & 108 & 98 & 140 & \\
\hline Cupressaceae & TKBG & $\begin{array}{l}\text { Metasequoia glyptostroboides } \mathrm{Hu} \& \\
\text { W.C. Cheng }\end{array}$ & 100 & 100 & 104 & 132 & \\
\hline Podocarpaceae & JDBG & $\begin{array}{l}\text { Podocarpus macrophyllus (Thunb.) } \\
\text { Sweet }\end{array}$ & 116 & 99 & 112 & 104 & \\
\hline Aquifoliaceae & TUAT & Ilex integraThunb. & 125 & 98 & 115 & 136 & \\
\hline Podocarpaceae & TKBG & $\begin{array}{l}\text { Podocarpus totara G. Bennet ex D. } \\
\text { Donn. }\end{array}$ & 127 & 104 & 120 & 107 & \\
\hline Mean (M) & & & 92.8 & 96.5 & 65.0 & 97.6 & \\
\hline $\begin{array}{l}\text { Standard } \\
\text { Deviation }(\sigma)\end{array}$ & & & 25.1 & 15.2 & 27.8 & 25.7 & \\
\hline $\mathrm{M}-0.5(\sigma)$ & $*$ & & & & 51.1 & 84.7 & \\
\hline $\mathrm{M}-1(\sigma)$ & $* *$ & & & & 37.2 & 71.9 & \\
\hline $\mathrm{M}-1.5(\sigma)$ & $* * *$ & & & & 23.3 & 59.0 & \\
\hline $\mathrm{M}-2(\sigma)$ & $* * * *$ & & & & 9.4 & 46.1 & \\
\hline
\end{tabular}

$\mathrm{R} \%$ : percentage of radicle length compared with the control; $\mathrm{H} \%$ : percentage of hypocotyl length compared with the control; Criteria $\left({ }^{*}\right)$ were categorized by "Standard Deviation Variance" (SDV) based on radicle elongation at $50 \mathrm{mg}$ of leaf litter; Asterisks indicate the exhibited strength of inhibitory activity; ****: strongest inhibitory activity, **: strong inhibitory activity, **: medium inhibitory activity and *: low inhibitory activity; $\dagger$ : INDO: Central Java, Indonesia; JDBG: Jindai Botanical Garden; KSBG: Koishikawa Botanical Garden; TKBG: Tsukuba Botanical Garden; TUAT: Tokyo University of Agriculture and Technology, Fuchu campus and YMBG: Yumenoshima Botanical Garden.

germination of sunflower seeds (Muhartini, 1987). In previous studies, both Duranta repens leaves and Nandina domestica leaves exhibited allelopathic activity on lettuce (Appiah et al., 2015; Takemura et al., 2013). In comparison, $S$. macrophylla leaf litter has been observed and showed allelopathic potential higher than Nandina domestica but lower than
Duranta repens. The results of this research suggest that leaf litter contributed to inhibition of plant growth under S. macrophylla trees.

The radicle and hypocotyl elongation percentages of the lettuce seedlings varied depending on the milligram dry weight (D.W.) of leaf litter species (Table 1). When treated with $10 \mathrm{mg}$ D.W. and $50 \mathrm{mg}$ D.W. samples, 
the radicle elongation percentages ranged $29-127 \%$ and $9-120 \%$, respectively, compared with the control. Meanwhile, hypocotyl ranged $54-122 \%$ and $28-140 \%$, respectively. Inhibition of radicle lettuce seedlings $\sim 50 \%$ was exhibited in 3 species at $10 \mathrm{mg}$ D.W. and 15 species at $50 \mathrm{mg}$ D.W., respectively. The results indicate that increasing leaf litter dry weight enhanced the inhibition of radicle growth in lettuce seedlings.

Direct interaction between leaf litter and lettuce seeds is prevented by the presence of a bilayer agar. Movement of allelochemicals from leaf litter is facilitated by the principle of diffusion. As Table 1 shows, the radicle elongation in lettuce seedlings was less than that of hypocotyls with either $10 \mathrm{mg}$ or $50 \mathrm{mg}$ of dried leaves. This might be related to the absorption and concentration of phytotoxins in the root tissue by direct contact with the allelochemicals (Morikawa et al., 2012).

\section{Growth-inhibitory activity of S. macrophylla leaf litter}

The inhibitory activity on lettuce seedling growth can be represented as effective concentration $\left(\mathrm{EC}_{50}\right)$ required to induce halfmaximal inhibition of growth (Takemura et al., 2013). Determination of concentration intervals was started by evaluating a wide range of concentrations - e.g. 0.1, 1, 3, 10, 30, $100 \mathrm{mg}$ dry weight (D.W.) equivalent $\mathrm{mL}^{-1}$ (mg D.W. eq. $\mathrm{mL}^{-1}$ ) (data not shown). The second concentration interval was determined in the specific range of concentration, which included the half-maximal inhibition of lettuce seedling growth. The range of specific concentration interval was 1, 3, 5, 7, 9 mg dry weight (D.W.) equivalent $\mathrm{mL}^{-1}$ (mg D.W. eq. $\left.\mathrm{mL}^{-1}\right)$. The allelopathic potential of $S$. macrophylla leaf litter is illustrated in Figure 1.

It showed that increasing S. macrophylla leaf litter concentration is concomitant with inhibition of radicle lettuce seedling growth compared with the control. Twenty species that have strong growth-inhibitory activity had an $\mathrm{EC}_{50}$ ranging from 0.28 to $6.90 \mathrm{mg}$ F.W. eq. $\mathrm{mL}^{-1}$ (Takemura et al., 2013; NIEAS, 2016). Based on the linear regression analysis, the $\mathrm{EC}_{50}$ of $S$. macrophylla was estimated to be $3.25 \mathrm{mg}$ D.W. eq. $\mathrm{mL}^{-1}$ and was considered to have strong growth-inhibitory activity on lettuce radicle elongation. Based on the $\mathrm{EC}_{50}$ value, S. macrophylla has stronger growthinhibitory activity than Nandina domestica (Berberidaceae; estimated $\mathrm{EC}_{50}: 6.21 \mathrm{mg} \mathrm{F.W}$. eq. $\mathrm{mL}^{-1}$ ) and related to the previous study using sandwich method bioassay. The interaction between S. macrophylla leaf litter and lettuce seedlings investigated in this study is novel because previous research has only explored plant-microbe and plant-insect interactions.

S. macrophylla leaves contain limonoid, essential oils, and polyphenols (quercetin, catechin, and kaemferol) (El Zalabani et al.,

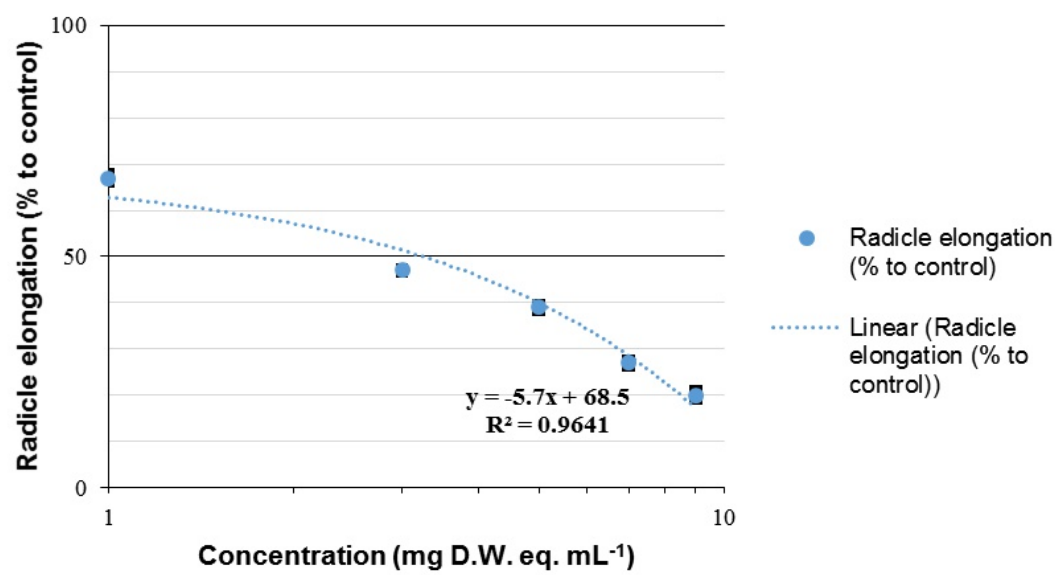

Figure 1. Effect of mahogany (Swietenia macrophylla King) leaf litter on the growth of lettuce seedlings based on a growth-inhibitory effects bioassay. Each value represented mean \pm S.D. from three independent experiments. Range of concentration is shown in logarithmic scale and exhibited unit of mg S.macrophylla leaf litter dry weight (D.W.) equivalent $\mathrm{mL}^{-1}$. The effective concentration of 50 percent $\left(\mathrm{EC}_{50}\right)$ could be calculated based on linear regression analysis. 
2012; Moghadamtousi et al., 2013; Paritala et al., 2015; Roy and Saraf, 2006). Limonoid is insoluble in the water but soluble in the alcohol. It might be extracted by methanol 90\% but solvent evaporation caused binding of limonoid to the filter paper. When distilled water added to the filter paper, limonoid might not be soluble in the distilled water. Therefore, it might not contribute to induce inhibition of radicle elongation in pregerminated lettuce seedlings. Meanwhile, the lone pair electron in the hydroxyl group ($\mathrm{OH}$ ) of polyphenol might bind with hydrogen atom of methanol $90 \%$. Furthermore, $S$. macrophylla leaf litter contained lignin and tannin included in the polyphenol group. Both of them might be extracted by methanol $90 \%$. Therefore, the possible allelochemicals were polyphenol, lignin and tannin. The possible allelochemicals will interact on the radicle of lettuce seedling and might inhibit radicle and hypocotyl elongation. Meanwhile, total activity method could be used to investigate induction of allelopathic activity, either by a single compound or multiple compounds.

Further research should investigate the allelopathic potential of $S$. macrophylla leaf litter towards weeds or crops using a specific activity $\left(\mathrm{EC}_{50}\right)$ bioassay, determine the chemical constituents in S. macrophylla leaf litter using the total activity method, and observe polyphenols as allelochemicals using an isolation method and total activity.

\section{Conclusions}

S. macrophylla exhibits strong allelopathic potential on lettuce using the sandwich method. The effective concentration $\left(\mathrm{EC}_{50}\right)$ of $S$. macrophylla leaf litter was estimated to be $3.25 \mathrm{mg}$ D.W. eq. $\mathrm{mL}^{-1}$ and was considered to have strong specific activity. The results of the present study are new findings that suggest a possibility of allelopathic potential of leaf litter in plant-plant interaction under S. macrophylla trees.

\section{Acknowledgements}

We would like to express our gratitude to Dr. Purnomo, M.Si., for his valuable supervision in the identification of $S$. macrophylla. We are also grateful to Kwame Sarpong Appiah, M.Agr., and Hay Pharith, M. Agr., for their laboratory practice guidance in the laboratory of International AgroBiological Resources and Allelopathy, IEAS, TUAT, Japan. This research was supported by the Short Term Exchange Program at Tokyo University of Agriculture and Technology (STEP@TUAT 2015-2016) with a JASSO Scholarship. This study was part of a Master's degree research at Universitas Gadjah Mada funded by a BPPDN-DIKTI Scholarship.

\section{References}

Appiah, K.S., Li, Z., Zeng, R., Luo, S., Oikawa, Y., and Fujii, Y. 2015. Determination of allelopathic potentials in plant species in Sino - Japanese floristic region by sandwich method and dish pack method. IJBAS., 4, 381-394.

Blum, U. (2011) Plant - plant allelopathic intraction. New York: Springer Science+Bussiness Media B.V.

Duke, S.O. 2015. Proving allelopathy in cropweed interactions. Weed Sci., Special issue, 121-132.

Einhelling, F.A. (1995) Allelopathy: current status and future goals. In Allelopathy: organisms, processes, and applications (Inderjit, K.M.M. Dakshini, and F.A. Einhelling, eds.) pp 1-24. American Chemical Society.

El Zalabani, S.M., El-Askary, H.I., Mousa, O.M., Issa, M.Y., Zaitoun, A.A., and Abdel-Sattar, E. 2012. Acaricidal activity of Swietenia mahogani and Swietenia macrophylla ethanolic extracts against Varroa destructor in honeybee colonies. Exp. Parasitol., 130, 166-170.

Fan, K-C., His, H-C., Chen, C-W., Lee, H-L, and Hseu, Z-Y. 2011. Cadmium accumulation and tolerance of mahogany (Swietenia macrophylla) seedlings for phytoextraction applications. J. Environ. Manage, 92, 2818-2822.

Farooq, M., Jabran, K., Cheema, Z.A., Wahid, A., and Siddique, K.H. 2011. The role of allelopathy in agricultural pest management. Pest Manag. Sci., 
67, 493-506.

Fujii, Y., Parvez, S.S., Parvez, M.M., Ohmae, Y., and Uda, O. 2003. Screening of 239 medicinal plant species for allelopathic activity using the sandwich method. Weed Biol. Manag., 3, 233-241.

Fujii, Y., Shibuya, T., Nakatani, K., Itani, T., Hiradate, S., and Parvez, M.M. 2004. Assessment method for allelopathic effect from leaf litter leachates. Weed Biol. Manag., 4, 19-23.

Fujii, Y., Pariasca, D., Shibuya, T., Yasuda, T., Kahn, B., and Waller, G.R. (2007) Plantbox method: a specific bioassay to evaluate allelopathy through root exudates. In Allelopathy new concepts and methodology (Y. Fujii and S. Hiradate, eds.) p 43. Science Publishers.

Gniazdowska, A and Bogatek, R. 2005. Allelopathic interactions between plants: Multi site action of allelochemicals. Acta Physiol. Plant., 27, 395-407.

Jabran, K., Mahajan, G., Sardana, V., and Chauhan, B.S. 2015. Allelopathy for weed control in agricultural systems. Crop Prot., 72, 57-65.

Krisnawati, H., Kallio, M., and Kanninen, M. (2011) Swietenia macrophylla King: Ecology, silviculture and productivity. Bogor: CIFOR.

Mardani, H., Kazantseva, E., Onipchenko, V., Fujii, Y. 2016. Evaluation of allelopathic activity of 178 Caucasian plant species. Int. J. Basic Appl. Sci., 5, 75-81.

Moghadamtousi, S.Z., Goh, B.H., Chan, C.K., Shabab, T., and Kadir, H.A. 2013. Biological activities and phytochemicals of Swietenia macrophylla King. Molecules, 18, 10465-10483.

Morikawa, C.I.O., Miyaura, R., de Lourdes Tapia y Figueroa, M., Rengifo Salgado, E.L., and Fujii, Y. 2012. Screening of 170 Peruvian plant species for allelopathic activity by using the Sandwich Method. Weed Biol. Manag., 12, 1-11.

Muhartini, S. (1987) Allelopathy mahoni (Swietenia mahogany Jacq.) Terhadap Perkecambahan dan Pertumbuhan Tanaman Disekitarnya. Research manuscript. Yogyakarta: Faculty of Agriculture UGM.

NIEAS. (2006) Screening of plant species with high allelopathic activity. http://www.niaes.affrc.go.jp/sinfo/ result/result30/result30_44.pdf. Accessed on November 8th, 2016

Nugroho, S.A. (2014) Litterfall production and semi aerobic decomposition of leaf mahogany (Swietenia macrophylla King.). Thesis manuscript. Bogor: Sekolah Pascasarjana IPB. http://repository.ipb.ac.id/handle/12 3456789/69250. Accessed on November, 2nd, 2016.

Paritala, V., Chiruvella, K.K., Thammineni, C., Ghanta, R.G., and Mohammed, A.,2015. Phytochemicals and antimicrobial potentials of mahogany family. Brazilian J. Pharmacogn., 25, 61-83.

Rice, E.L. (1984) Allelopathy. Florida: Academic Press Inc.

Roy, A. and Saraf, S. 2006. Limonoids: overview of significant bioactive triterpenes distributed in plants kingdom. Biol. Pharm. Bull., 29, 191-201.

Singh, H.P., Batish, D.R., and Kohli, R.K. 2003. Allelopathic interactions and allelochemicals: new possibilities for sustainable weed management. CRC. Crit. Rev. Plant Sci., 22, 239-311.

Soares, M.G., Batista-Pereira, L.G., Fernandes, J.B., Corrêa, A.G., Da Silva, M.F.G.F., Vieira, P.C., Rodrigues Filho, E., and Ohashi, O.S. 2003. Electrophysiological responses of female and male Hypsipyla grandella (zeller) to Swietenia macrophylla essential oils. J. Chem. Ecol., 29, 2143-2151.

Takemura, T., Sakuno, E., Kamo, T., Hiradate, S., Fujii, Y. 2013. Screening of the growthinhibitory effects of 168 plant species against lettuce seedlings. Am. J. Plant Sci. 4, 1095-1104.

Tambaru, E. (1998) Pengaruh hasil dekomposisi seresah mahoni (Swietenia macrophylla King) terhadap perkecambahan biji, infeksi mikoriza vesikular-arbuskular 
dan pertumbuhan bibit akasia (Acacia mangium Wild.). Thesis. Yogyakarta: Faculty of Biology UGM.

Weir, T.L., Park, S.W., Vivanco, J.M. 2004. Biochemical and physiological mechanisms mediated by allelochemicals. Curr. Opin. Plant Biol., 7, 472-479.

Whitmore, T.C. (2003) Mahogany: tree of the future. In Big-Leaf Mahogany Genetics, Ecology, and Management (A.E. Lugo, J.C.F. Colón and M. Alayón, eds.) pp. 1-5. Springer-Verlag. 